\title{
The Cultural Composition and Humanistic Trajectory in the History of Soochow City
}

\author{
Xinyi Zhang ${ }^{1, *}$
}

${ }^{1}$ College of Art and Design, Zhejiang Business College, Hangzhou, Zhejiang, China
${ }^{*}$ Corresponding author. Email: 63760465@qq.com

\begin{abstract}
This article starts from the retrospection of Soochow's historical culture. From the collection and excavation of historical data on human history, it finds that the "Yuze Mountain" in Taihu Lake was the "Fishing Place" of "Shun", and Soochow City was the fief of Xu, the second son of Zhou tribe's first ancestor Qi because of his contribution on water-control with Dayu. These historical materials can not only be used as the "top-level design" of Soochow history and culture; they can also prove Ji Xu, the meritorious statesman of the water-control of Taihu Lake Basin, as the founder of the history of the Gusu region, and prove Zhufan as the pioneer of Soochow; these studies can make historical localization set based on Zhu Fan as the pioneer of Soochow and Wu Zixu as the founder, to provide a reference for local history studies.
\end{abstract}

Keywords: Soochow, ancient city development, landform

\section{INTRODUCTION}

The loftiness and greatness of nature, and the understanding, awe, respect and love of the beauty of nature are one's style, taste and realm of life. The beauty of the human mind and the natural landscape are inseparable. Michelle Laurie, an honorary professor at the University of California, and an expert in urban landscape design, regards the "primitive process of landform formation as the great natural landscape in the world" and as "being comparable as the goal of the landscape design process". City is a natural region's development process and category, and it is a mark of the accumulation of human civilization. However, no matter how a city evolves or renews, it cannot be separated from its own history and culture; it continuously enriches and accumulates through time and space, thereby distinguishing this city from other cities' unique cultural symbols, and fully highlighting the foundation of urban civilization.

\section{DEDUCTION OF CULTURAL CONTEXT OF SOOCHOW URBAN AREA}

The evolution of the Soochow context can begin with Shun's "Yu Leize" in the era of the ancient "Five Emperors" for the following reasons:

\section{A. "Yuze Culture" in the "Five Emperors" era}

In the "Five Emperors" era in ancient China, historical records recorded the place where Emperor Shun "Yuze" (fishing in lake) in the south Taihu Lake in China. As "Historical Records: The First Five Emperors" [1] contains, "舜耕历山, 渔雷 泽, 陶可浜。(Shun carried out farming in Lishan Mountain, fishing in the Leize, making pottery in Kebang.) " Which is the place of "渔雷泽"? Although the address is not clearly stated in the "Historical Records", the author learned from "History of the Later Han Dynasty: County Countries (4)" that: 吴本国。震泽东西, 后名具区泽。 (In the country of $\mathrm{Wu}$, there is a huge lake covered from east to west, later it is calles as Quze.)"[2] In its "Note 1", it reads: "越绝日: 吴大成, 阅闾所造, 周 四十七里二百一十步二尺。又有伍子胥城, 居巢城。 (Yuejue said: There is a big city of $\mathrm{Wu}$, which is built by He Lv. The circumference of the city is forty-seveb li two hundred and ten bu and two chi. There is also a Wu Zixu city, named Juchao City.)" Liu Zhao's "Note 2" also contains: "尔雅十薮, 吴越之 间有具区, 郭理日县南太湖也。中有包山, 山下有洞庭, 穴 道潜行水底, 去无所不通, 号为地脉。越绝书日: 湖周三万 六千顷。又有大雷山、小雷山, 周处风土记日舜渔泽之所。 臣昭案, 此僻在威阳是也。(As Erhya recorded, among tens of lakes, there is a big lake between $\mathrm{Wu}$ and Yue. Guo Pu called it as the county's South Taihu Lake. In this area, there is the Baoshan Mountain. There are caves and halls under the mountain, with passages under the water flowing to everywhere, 
called leylines. It is written in Yuejue that: The lake covered thirty-six thousand qing. There are also Dalei Mountain and Xiaolei Mountain. Natural Conditions and Social Customs of Zhouchu said it as the fishing place of Shun. I, Zhao, record this at Xiangyang.)" This shows that between Dalei Mountain and Xiaolei Mountain in South Taihu Lake is Shun's "泽渔" place, that is his fishing place; in other words, this is the birthplace of China's original ecology "Yuze culture". Since then, relevant historical records such as "Fishing City" and "Fishing Garden" have continued, such as Zhu Changjiu's "Continuation of Maps and Records of Wu Counties" in Song Dynasty: "鱼城在吴县的横山 下，遗址尚存。横山之旁，冈势如城郭状，今犹隐隐然。 (Fishing City is under the Hengshan Mountain in $\mathrm{Wu}$ County, and the site still exists. Beside Hengshan, the potential of the ridge is like a city, and it is still indistinct now.)"[3] For another example, during the Qianlong reign of the Qing Dynasty, Song Zongyuan of Changzhou was rebuilt at the former site of Wanjuan Tang and named "网 师园 (Wangshi Garden)". He used the name of Wangshi and also took the old meaning of Shi Yuzhi's "渔隐 (yu yin)". The garden has become a world-class model of superbly selected Soochow private gardens in the works of western landscape architects, which is also a cultural phenomenon that reflects the city's "Yuze culture" from different perspectives.

\section{B. "Water management culture" of Dayu fighting a flood}

In ancient China, when Dayu governed the water, Qi's second son Xu had helped Dayu with the water-control. Because of his excellent watercontrol in the Taihu Lake Basin, Soochow became a fief of $\mathrm{Xu}$. It is said that $\mathrm{Yu}$ and $\mathrm{Xu}$ held a tribal chief meeting in Xishan Mountain, Taihu Lake more than 4,000 years ago to coordinate and jointly manage the water. Through the leadership of ancestors of $\mathrm{Wu}$, the floods were diverted into the sea. "三江既入，震泽底定 (Three rivers entered the sea, and Zhenze was settled)". Due to the brilliant achievements of water-control by $\mathrm{Xu}$, Shun assigned Soochow as a flef of $\mathrm{Xu}$. In response, Jin Youli quoted in the "Piling Records" in "Preparation for the Taihu Lake": "水平王, 后稄庶 子, 佐禹治水, 至会稽, 海人俊导, 歾而视之。(Lord Shuiping, Hou Xun's second son, helped Yu to manage the rivers, teaching and leading people, who had died young and been regarded as respectful.)" Wang Fu of Han Dynasty said in "Qianfu Said": "盖胥者, 舜起名, 佐禹治水有功, 封为 吴者也。(Xu, named by Shun, making achievements in helping with Yu's water-control, was rewarded with $\mathrm{Wu}$.)" At that time, Xu's fief was named as "甄 青 (zhen qing)" (referred in "Bamboo Annals"). After it was rewarded to $\mathrm{Xu}$, it was called as "姑胥 (gu $\mathrm{xu})^{\prime}$. In the ancient pronunciation, 胥 and 苏 pronounced as the same, so it is also called "姑苏 (gu su)"; "姑" is the prefix consonant, and "胥" is that the person's name became the country's name; it can be seen that at that time, Guxu was a country of the Xia Dynasty, and Guxu's "water management culture" also came from this.

\section{C. "Shipbuilding culture" of the Fuchai marine}

Gouwu Country was located in the water town of Jiangnan. Therefore, it attached great importance to the development of the shipbuilding industry. The level of its shipbuilding technology was also very high. The sea vessels it built were "flatbottomed and square-headed", using a quadrangular sail with a plate frame at the bow to reduce the resistance of the ship. In the shipbuilding design, the corner tower principle of curved side chords and wide beams was also used to widen the deck and increase the position of the ship to make the structure strong and adaptable. "Taking a boat as a carriage, and taking an oar as a horse", as the "boat division" of the navy has become Wu's military service, according to the "Zuo Zhuan" records, in the 14th year of King Zhou Jing (506 BC), Wu's 30,000 water and land division carried out the "Boju battle". The army first took the battleship and headed up from the Huai River to obtain five battles and five victorious battles, going all the way to the capital city of $\mathrm{Chu}$, which showed the power of Wu's marine. [5] Wu and Yue's "Fu Jiao Battle" was a famous water battle in the history of the war between the two countries. It took place between the Maji Mountain and the Dongting Mountain in the Taihu Lake, and the Yue's army was defeated. After this war, Yue was almost destroyed. Goujian, the King of Yue, served Fuchai as a slave and as well as his wife, and he was released back to Yue three years later. It is said that the water battle involved more than 300 ships and more than 7,000 soldiers injured and dead on both sides. According to the scale of the war, Wu's shipbuilding industry was quite developed and the shipbuilding technology was superb. For example, the king ship was a large warship under the command of King $\mathrm{Wu}$, and its scale was extremely magnificent. "Book of Yue Jue" has recorded the type of boat in the country at that time, such as the large wing, the middle wing, the small wing and the Tumao (a kind of ship), building ships, bridge ships and other forms of ships. The large wing ship was 12 feet long and 1 foot 6 feet wide. It can carry more than 90 people, 50 people paddle, 3 people support the rudder, and the rest are soldiers.

According to "Zuo Zhuan": In 485 BC, King of Wu led his army to go north with Lu, Bang, and Tan to fight Qi together. Xu Cheng led the ship division to enter the sea through the Yangtze River estuary, sailing thousands of miles to fight Qi in the area of the Yellow sea of today, but defeated by 
Qi's army. This naval battle is known as the origin of the Chinese Navy. To date, the shipbuilding industry has continued. Taihu Fishing Village, Guangfu Town, Wuzhong District, Soochow City, is the largest inland fishing port in China in recent years. Here, there is a strong ship custom culture, and there are nearly a thousand fishing boats in the original style. During the capture season, thousands of sails raced and the scene was extremely spectacular.

\section{D. "Smelting culture" of Gan Jiang casting sword}

Why did $\mathrm{Wu}$ become one of the "five hegemons" later in the Spring and Autumn Period in the short term? This was related to the rapid enhancement of Wu's strength at that time. In particular, its bronze smelting and casting industry was extremely prosperous, and its smelting technology was very sophisticated. Its most famous smelting masters were Gan Jiang and Mo Ye. The classic story of smelting and casting swords in historical books is the memory of that history. Soochow Gan Jiangfang Lane is a legendary area of $\mathrm{Wu}$ Guo handicraft industry in the Spring and Autumn Period. There is still a tomb of Gan Jiang outside the gate of Soochow. Its cast iron sword is famous throughout China. Wu Wangjian, unearthed from the Mashan Brick and Tile Factory in Jiangling, Hubei, is a wonderful work of Soochow smelting culture. Therefore, Soochow's smelting industry is the oldest and most glorious in the history of metallurgy in China. The "History of Chinese Metallurgy" edited by the China Iron and Steel Institute stated: "The discovery of iron in Chengjiaqiao (Nanjing of $\mathrm{Wu}$ ) Ironware appeared in the sixth century BC, which was 1900 before European pig iron smelting. "

\section{E. Unparalleled "garden culture"}

Gardens in Soochow are originated from the Spring and Autumn Period, developed in the Sui and Tang Dynasties, flourished in the Song Dynasty, and reaching the peak in the Ming and Qing Dynasties. In the Spring and Autumn Period, King of Wu began to build gardens and annexes for hunting and resting; He Lv digged the Xiajia Lke, and $\mathrm{Fu}$ Chai built the Gusu Pavilion and Changzhou Garden. "Wu and Yue in the Spring and Autumn Period" notes as: "姑苏台, 三年聚材, 五年建 成，远望高达二百余里。(Gusu Pavillion, its materials were gathered in three years, and it was completed in five years, on which you can view the scenery in more than 200 li.)" [4]. By the Ming Dynasty, there were 271 private gardens in Soochow, and more than 60 gardens are still preserved. Among them, Humble Administrator's Garden and Lingering Garden are listed in China's four famous gardens, and each of them constitutes a picture of winding landscapes. The beauty lies in the layered structure.
The pavilions and corridors are patchwork, giving a sense of well-being and serenity. They also have elegant gardening skills that even each corner is arranged delicately and humorously, achieving the aesthetic conception of the scene-feeling blended. In Song Dynasty, Su Shunqin wrote in "Canglang Pavilion": "前竹后水, 水之阳文竹, 无穷极; 澄川翠干, 光影会合于轩户之间, 尤以风月为相宜。( There are bamboos in the front and there is water in the behind, with asparagus fern by the south side of the water, infinite poles; the water is clear and the bamboos are green. The light and shadow integrated with each other and reflected among the buildings. It makes people feel comfortable especially when there is breeze and bright moon.)" Here, the bamboo forest in the front and the river in the back are used to enrich the garden landscape by borrowing scenery. Zheng Wenming in Ming Dynasty pointed out in the "The Humble Administrator's Garden of Wang Family" that the beauty of the Humble Administrator's Garden art lies in "orderly in chaos" and "laws in change". Its layout is centered on water, with large pools and surrounding landscapes, playing wonderful music, reflecting the delicate art of its gardens.

\section{F. The most of the ancient "city wall culture"}

The existence and abandonment of a city is behind the era of loose and tense. The deep context of the ancient city of Soochow, its ancient city wall is a historical testimony of the passing of time; it is not only a symbol of the ancient city's culture, but also a microcosm of the urban era and historical interpretation.

The city wall was called "城池 (city pond)" in the ancient times, and its meaning is "digging the soil for the pond, and cultivating the soil for the wall". The ancient city wall of Soochow was built in the Spring and Autumn Period. It was called $\mathrm{He}$ Lv City in ancient times, its regional name was Gusu, and its water name was Zhenze. The ancient city has been repeatedly built and destroyed repeatedly in history. The history of its construction according to the "Historical Records: Justice" contains: "太伯居梅里, 在常州无锡县, 东南六十里, 至 十九世孙寿梦居之, 号勾吴。寿梦卒, 诸杽南徏吴。 (Taibo lived in Meili, sixty li southeast from Wuxi County, Changzhou. His family lived here until his grandson of the 19th generation named Shoumeng, whose assumed name was Gouwu. After Shoument died, Zhu Fan moved southward to Wu.)" "Changzhou County Chronicle Vol. 8" note for this as: "吴自泰伯筑城于梅里, 号向吴, 至寿梦十九世皆为 都, 盖无锡之境也。其后诸杽南徏六十里, 即今吴地。当时 未大兴土木。( $\mathrm{Wu}$, since Taibo built the city in Meili, which was named as Gouwu. Until the 19th generation Shoumeng, it was the capital, which was in the area of Wuxi. Then Zhu Fan moved sixty li southward to the $\mathrm{Wu}$ area of current days. The city 
hadn't been built largely at that time.)" The place where Zhu Fan "moved to $\mathrm{Wu}$ " was the "small town" in the He Lv ancient city built by Wu Zixu.

This capital city of Wu suffered severe damage after experiencing the war of annihilating $\mathrm{Wu}$ (473 BC) and Chu destroying Yue. During the fifteen years of King Chu Kaolie (248 BC), in the late Warring States period, it was rewarded to Huang Xie, the country's prime minister Lord Chunshen, with the $\mathrm{He} \mathrm{Lv}$ ancient city as the capital. He inherited the city wall culture for restoration and reconstruction, and also built a beautiful Taoxia Palace. Sima Qian said in the "Historical Records": "吾适楚, 观春申君故城, 宫室盛其哉。(When I was in Chu, I viewed the Shenjun ancient city. The palace and buildings are splendid.)" By the end of the Tang Dynasty, the ancient city had been destroyed many times due to the secession of military governors. After the rule of Qian Miao of $\mathrm{Wu}$ Yue, according to the "Soochow Government Record" of Tongzhi, the fifth generation "五代梁龙德二年 （922），钱氏复以砖梵, 高二丈四尺, 厚二丈五尺, 里外 有濠, 以前城墙为土筑, 这是苏州首次用砖砌城墙, 显得格 外壮丽雄伟。( The fifth generation, the second year of Liang Longde (922), Qian used the bricks to repair the city wall, with the height of twenty-four chi and the thickness of twenty-five chi. There are ditches in both side of the wall. The city wall was built by soil before and this was the first time that Soochow used the bricks to build the wall, being extremely splendid.)"

However, in Jianyan period in the Southern Song Dynasty, it experienced an unprecedented calamity by the Mongolian Jin Wushu, the buildings in the city were barely complete, and they were restored after several major repairs over a century. The results of its repairs were shown in " Picture of Pingjiang". According to the history book: "Picture of Pingjiang" was engraved by Lu Ting in the second year of Shao Ding in the Southern Song Dynasty when the county defender Li Shouming rebuilt Pingjiang Bazzar. There are 65 double walled walls, water, land and gates, and workshops and 314 bridges in the picture, as well as the government office, military stop, schools, platforms, pavilions, gardeners, temples, temples, monuments, neighborhoods, rivers, lakes, and hills, etc., marked more than 610 buildings.

During the Ming and Qing Dynasties, although the city walls of Soochow were repeatedly damaged, they were gradually built and restored, maintaining the context of the "city wall culture". After the founding of the People's Republic of China, when the State Council approved the first batch of historic and cultural cities in 1982, the attached brief introduction to the cities included comments on Soochow: "In the Spring and Autumn Period, it was the capital city of Wu. In Sui and Tang dynasties, it was Soochow government office, and in Song dynasty it was Pingjiang government. Historically, it was a prosperous water city in Jiangnan with a flourishing business and handicraft industry. Many well-known ancient gardens are preserved, and the essence of the garden arts built in Song, Yuan, Ming, and Qing Dynasties in China is concentrated", which fully reflects the historical positioning and high respect of Soochow's ancient city culture by the state's highest administrative organ.

In addition, there are "canal culture" and "agricultural culture" that have long been famous and will not be repeated here.

\section{RETRACING THE PROMINENT HISTORICAL FIGURES IN THE EARLY DEVELOPMENT OF SOOCHOW CITY}

Historical materialism tells people that the people are the creators of history and the decisive force for advancing history. And on the premise of affirming that the people are the creators of history, they also recognize the important influence and driving role of important figures in history, especially outstanding figures such as leaders of the masses, which also makes sense on the development of local history. To this end, the author traces and researches the prominent historical figures who developed the Soochow area and cities in the early days as follows. They are:

\section{A. Ji Xu is the earliest developer of Soochow}

As mentioned earlier, Gusu is considered a fiefdom issue because of Xu's water management achievements. What kind of character was Ji Xu? It is said that in ancient China, since the death of Emperor Yao, Shun, the leader of the Yu tribe, was promoted to be the chief warrior. When Shun ordered $\mathrm{Yu}$ to control the water, Yu was assisted by $\mathrm{Qi}$ and Qi's second son Xu. According to "Historical Records: Biographic Sketches of Zhou", "周后稄名弃, 其母有部氏女, 日姜嫄。(In Houzong of Zhou, there is a person named Qi, of whose mother is Tai's daughter named Jiang Yuan.)" [6]. The leader of the Zhou tribe Houzong named as Qi. He sometimes planted crops such as mochi. He was also good at choosing fertile land to grow crops, so that the crops could be harvested. In order to give full play of Qi's specialties, Shun resigned from the official position in charge of agriculture. Three years later, due to the remarkable performance of what Qi's had done on his responsible agriculture, the surname Ji was also given to Qi as well as Tai area as the fief. At that time, Xu was also rewarded by Shun because of his achievements in water management. Zhu Hong said in his book "Detail Discussion on Taibo": In the old Taihu Lake, the Majishan watershed in the Dongting West Mountain Xiaoxia Bay had "Palace of Lord 
Shuiping", which all commemorated the relics of the Xu's water management [7]. Because of the profound influence of this history, the Zhou tribe from the first ancestor Qi to the Taibo generation after the 27th generation, chose Meili of Wu to find their ancestors, which was also one of the reasons for Taibo to go to $\mathrm{Wu}$. Ji $\mathrm{Xu}$ was born in an agricultural tribe that is good at farming. As a fief, Gusu region, how to develop agriculture at that time has yet to be verified. However, the latter advantage that has developed since then has become a well-known "hometown of fishing rice" at home and abroad. However, it has certain relevance. Therefore, the author personally suggests that the local history scholars to locate Ji Xu as the earliest developer in Soochow is relatively objective and accurate.

\section{B. Zhu Fan, king of Wu, was the founder of Soochow}

Zhu Fan, whose given name is Ye, the eldest son of King of Wu Shoumeng's 18th generation, took over in the 24th year of Ling King of Zhou. According to historical records such as "Historical Records: Official Records" "Changzhou County Chronicle" and "Soochow City Wall", there are related historical materials of "Zhu Fan moving southward to $\mathrm{Wu}$ ". After the Spring and Autumn Period of $\mathrm{Wu}$ Kingdom to Shou Meng "the beginning of the country was strong", due to the background of the state of the war between $\mathrm{Wu}$ and $\mathrm{Chu}$, and Chu's national strength was stronger than $\mathrm{Wu}$, in order to ensure the security of the country, the concept of migrating the country was proposed. But where can the migration go? The ancient book "Guanzi" reads: "凡立国都，非于大山之下，心于广川之 上; 高册近旱, 而水用足; 下册近水, 而沟防省。因天材, 就地利, 故城郭不必中规矩, 道路不必中准绳。(When setting the capital of a country, it will always be set up under the mountain and on the plain. The higher place is dryer, so it can use more water, and the lower place is closer to water, so it can dig a ditch to manage the water. Taking the advantage of the nature, the city doesn't have to be regular and the roads don't have to have a center.)" Its purpose is to take advantage of the situation in the mountains and rivers. Zhu Fan chose Gusu as the direction of the capital according to the above-mentioned principle of selecting the capital. This was an important decision that had fundamental significance for Soochow.

The original site of "Zhu Fan moving southward to Wu" was in the area of today's stadium and large park. It was originally a city in Soochow, that is, the "sub-city" built in the city when Wu Zixu built the He Lv city. The area of this soil city is "six hundred and sixty steps around". Since Qin set the Kuaiji County, experienced Han, Tang, and Song Dynasties, this sub-city was the seat of the county capital. After Zhang Shicheng in Ming Dynasty settled in the city, it was his palace. Later, Zhu Yuanzhang raised his army and burned it into ashes. After the Revolution of 1911, the authorities built Soochow Park on the ruins of sub-city, which is also called as "Park of Palace Ruins". Therefore, in terms of the contributions of Zhu Fan, king of Wu, in history, the author thinks that Zhu Fan was the leader and founder of Soochow.

\section{Wu Zixu was the founder of Soochow city}

$\mathrm{Wu} \mathrm{Zixu}$, a famous person of $\mathrm{Chu}$, was the second son of $\mathrm{Wu}$ She, a loyal officer of Chu. After Wu She and his eldest son were killed by Ping King of $\mathrm{Chu}, \mathrm{Wu}$ Zixu fled to $\mathrm{Wu}, \mathrm{He} \mathrm{Lv}$ named him as a "pedestrian", and recommended Sun Wuqi to the prosper national affairs. When $\mathrm{Wu}$ entered the early period of the He Lv era, due to the establishment of Wu's "no defense inside, no support outside", Wu Zixu adopted the principle of "building a city profile, setting up defensive positions, solid positions, and governing armory". He used the "象 天法地" (leaning on the natural condition) citybuilding method, and chose the transition zone of the low hill plain on the east side of Taihu Lake, that is, the place where the former Zhu Fan built the "离宫别宛" (palace name) to build the He Lv large city. Here is an excellent mountain and water environment, and the geographical advantage of being located in the country of water network translation, which is in line with the Fengshui method of "getting water for the first", and can fully interpret the "water city" pattern. Large city of $\mathrm{Wu}$ has been scattered small lakes in the northeast, and Taihu Lake in the west. It was surrounded by fortress-like mountains between the city and Taihu Lake. It is not only conducive to blocking the Taihu Lake flood, but also to build a natural defense system for ancient cities. That is to say, it is a military strategic highland that can be retreated, and attacked. Professor Wu Qingzhou of the Department of Architecture of Tsinghua University pointed out in the article "On the Experience of Flood Control and Waterlogging Prevention in Ancient Cities in China" in the 1980s: "Choosing the right city site is a key part of the ancient city planning to consider flood control and waterlogging prevention. Whether this problem is solved well or not will affect the future and fate of the city." As the site of Soochow has been selected so far, the site of the city has not changed, and the terrain is relatively high. Generally, the elevation is about 5 meters, which happens almost once in 50 years. In the text, three cities of Soochow, Wuxi and Shaoxing are used as typical examples of optimal site selection in ancient times.

The famous historian Gu Jiegang pointed out in the article "Ancient Chinese Cities": "Soochow is the place with the most historical relics. It was built 
by King of $\mathrm{Wu} \mathrm{He} \mathrm{Lv}$ and $\mathrm{Wu}$ Zixu. It has more than 2,400 years of history and is the oldest city in China. Due to various reasons, in the ancient cities, some of them were relocated to cities, some of them were barren, and they were more affected by the war. However, the ancient city of Soochow continued to exist, so historians called it 'the first in the country'" [8]. This article argues that it is necessary to determine $\mathrm{Wu}$ Zixu's status as the founder of Soochow. Because of the wisdom of the site selection, the scale and the courage of the city, he had the righteousness, the lofty quality of the country and the people, and held up the banner of his example.

\section{CONCLUSION}

Culture is the soul of a city, as well as the symbol and logo of the evolution of urban civilization. It is the result of the material and spiritual civilization created by human beings in long-term social practice. The material result of the transformation of nature by mankind is material civilization; while the objective world is being transformed, the subjective world of people is also transformed, and the spiritual production and spiritual life of society are developed. These two achievements are spiritual civilization. Tracing the origin of Soochow culture, it has a long history and is extensive and profound. It can be divided into three stages from the beginning of the ancient times, namely the "Yuze culture" and "water management culture" in the pre-Wu period, the "shipbuilding culture" and "smelting culture" in the Wu state, and the "garden culture" and "city wall culture" of the post-Wu stage.

The history of Chinese civilization begins at the beginning of the "Five Emperors" era of 5,000 years. In exploring the evolution of the geographical names of Soochow, it was discovered that it Zhou ancestor Qi's second son Xu's fief because of active water management with Dayu as a reward; At the same time, in the annotation of the "Book of Later Han Dynasty", it was found that "YuzeMountain" in Taihu Lake in this area was Shun's "fishing place". These historical materials can not only be used as the "top-level design" of Soochow history and culture; it can also make Ji Xu, the meritorious statesman of the water-control of Taihu Lake Basin, as the founder of the history of the Gusu region; take Zhufan as the pioneer of Soochow; it can set historical localization based on Zhu Fan as the pioneer of Soochow and Wu Zixu as the founder, to provide a reference for local history studies. At the same time, this can be used as evidence of Chinese multiculturalism, and it is also conducive to presenting new bright spots in the history and culture of Soochow.

\section{References}

[1] (Western Han) Sima Qian, Historical Records Vol. 01 Biography of Five Emperors the First [M]. Wang Liqi, trans. San Qin Publishing House, 2008. (in Chinese)

[2] (Song in the Southern Dynasties) Fan Ye, History of Later Han Dynasty: County Countries (4) [M]. Yi Li composed and trans. San Qin Publishing House, 2008. (in Chinese)

[3] (Northern Song) Zhu Changjiu, Continuation of Maps and Records of Wu Counties [M]. Jiangsu Local Literature Series, 1986. (in Chinese)

[4] (the Spring and Autumn Period) Zuo Qiuming, The Commentary of Zuo [M]. Wu Ruzhi, trans. San Qin Publishing House, 2008. (in Chinese)

[5] (Eastern Han) Zhao Ye, Wu Yue in the Spring and Autumn [M]. Cui Ye, trans. Shanghai Commercial Press, 1912. (in Chinese)

[6] (Western Han) Sima Qian, Historical Records: Biography of Zhou $[\mathrm{M}]$. Cai Linshan, trans. Beijing Limited Publishing Co. Ltd. 2015. (in Chinese)

[7] Zhu Hong, Detail Discussion on Taibo [M]. Shandong Pictorial Publishing House, 2011. (in Chinese)

[8] Gu Jiegang, Ancient Chinese Cities [J]. History Research and Teaching, 1983 (3): 2-5. (in Chinese) 